\title{
Surfactants in Acute Respiratory Distress Syndrome in Infants and Children: Past, Present and Future
}

\author{
Angela Amigoni $^{1} \cdot$ Andrea Pettenazzo $^{1} \cdot$ Valentina Stritoni $^{1} \cdot$ Maria Circelli $^{2}$
}

Published online: 16 May 2017

(c) The Author(s) 2017. This article is an open access publication

\begin{abstract}
There is a lack of definitive data on the effective management of acute respiratory distress syndrome (ARDS) in infants and children. The development and validation of the Berlin definition (BD) for ARDS and the Pediatric Acute Lung Injury Consensus Conference (PALICC) recommendations in children represented a major advance in optimizing research and treatment, mainly due to the introduction of a severe ARDS category. Proposed reasons for the lack of consistent results with surfactants in children and infants compared with neonates include different causes, type of lung damage (direct or indirect), timing and mode of administration as well as the type of surfactant used. Secretory phospholipase A2 plays an important role in inflammation and possible dysfunction
\end{abstract}

of surfactants in ARDS. Bronchoalveolar lavage (BAL) with normal saline and surfactant allows the removal of inhaled material, the recruitment of non-ventilating areas and the maintenance of the surfactant pool size. BAL with diluted surfactant allows rapid absorption of the surfactant at the air/liquid interface, which blocks the progression of pathological lung disease and in turn disrupts the inflammatory cycle. Importantly, it is now recognized that the type of surfactant, the time of administration and the method of administration could all play an important role in the management of ARDS, and there is evidence that surfactant is effective and well tolerated in children and infants with ARDS.
Angela Amigoni

angela.amigoni@aopd.veneto.it

Andrea Pettenazzo

andrea.pettenazzo@aopd.veneto.it

Valentina Stritoni

tinatoni_76@hotmail.com

Maria Circelli

m.circelli@chiesi.com

1 Paediatric Intensive Care Unit, Department of Women's and Child's Health, University Hospital of Padua, Via Giustiniani 3, 35128 Padua, Italy

2 Chiesi Farmaceutici Spa, Parma, Italy 


\section{Key Points}

ARDS is a multifactorial syndrome that causes significant morbidity and mortality in infants and children.

The BD can evaluate the severity of ARDS in children as shown by the decreased survival and reduced number of ventilation-free days in patients with severe ARDS compared with patients with mild and moderate ARDS.

Negative trial data have been published on the use of surfactants in infants/children with ARDS but it is important to evaluate every aspect of the selected treatment.

ARDS in infants and children is different from hyaline membrane disease-in children, as well as an underlying surfactant deficiency, there is inhibition/inactivation of endogenous surfactant. In these patients, removal of inhibitors should be performed before administration of exogenous surfactant.

The type of lung damage first needs to be established: exogenous surfactant therapy is useful in patients with direct lung injury.

BAL with normal saline and surfactant may show a synergistic therapeutic effect that allows the removal of inhaled material, the recruitment of nonventilating areas and the maintenance of surfactant pool size. BAL using a diluted surfactant solution followed by supplementation of exogenous surfactant with regular instillation has been effectively adopted in clinical trials.

The timing, dosage and type of surfactant used are of paramount importance. The earlier treatment is begun the greater the chance of a positive outcome.

There are reliable real-world data showing poroctant alfa is effective and well tolerated in children/infants with ARDS.

\section{Introduction}

Effective management of acute respiratory distress syndrome (ARDS), a pulmonary condition with overwhelming clinical consequences, remains elusive despite many years of ongoing research [1]. This is in part due to its complex pathogenesis and heterogeneous clinical features but also to the difficulties involved in conducting large-scale clinical trials, especially in paediatric patients. Intensity of scientific discussion surrounding the management of ARDS with surfactant iterates that it is an opportune time to review our current understanding. In this paper we discuss how the definition of ARDS has changed in recent years, outline the processes involved in the development of ARDS in infants and children, identify gaps in our knowledge and present available data on the use of surfactant.

\section{Defining Acute Respiratory Distress Syndrome (ARDS)}

A validated definition of ARDS is fundamental in designing clinical trials, assessing the benefits and risks of a given therapy, identifying subgroups of patients who may benefit from new therapies, and determining prognosis [2, 3]. Since its first description in the 1960s, considerable progress has been made in the understanding and management of ARDS. The American-European Consensus Conference (AECC) in 1994 defined acute lung injury (ALI) as respiratory failure of acute onset with a $\mathrm{PaO}_{2} / \mathrm{FiO}_{2}$ ratio $\leq 300 \mathrm{mmHg}$ and ARDS as a $\mathrm{PaO}_{2} / \mathrm{FiO}_{2}$ ratio $\leq 200 \mathrm{mmHg}$ [4]. Despite the fact that an 11-year-old and four teenagers were among the 12 patients initially reported by Ashburgh, the syndrome was termed 'adult respiratory distress syndrome' $[2,3]$. The AECC later recommended that 'adult' be changed to 'acute' to accurately reflect the fact that the syndrome occurs in both adults and children.

In 2012, the Berlin definition (BD) addressed many of the limitations of the AECC [5-7]. Essentially, according to the new BD, ARDS was considered as a unique pathophysiological process and was described by timing, radiographic changes, origin of oedema and severity. It was classified as mild, moderate or severe according to the $\mathrm{PaO}_{2} / \mathrm{FiO}_{2}$ ratio. The ALI term was not included in the BD because it was not useful and frequently used inappropriately.

\section{Berlin Definition of ARDS Validated for Adults: But What About Infants and Children?}

It has long been recognized that ARDS in infants/children is different from that in adults, and both the AECC and BD have limitations when applied to children. The European Society for Paediatric Neonatal Intensive Care (ESPNIC) evaluated BD validity for a paediatric population, reporting that in ages between 30 days and 18 months. It is mainly due to the introduction of a 'severe ARDS' category [7, 8]. 
It is suggested that the BD can better describe the severity of ARDS in children in comparison with the AECC definition, as shown by the decreased survival in patients with severe ARDS compared with patients with mild or moderate ARDS [9]. A subsequent study confirmed that in patients aged up to 15 years old who have ARDS, the BD can identify a subgroup of patients with distinctly worse outcomes, as shown by the increased mortality and reduced number of ventilator-free days in the severe ARDS group. The authors concluded that BD must not be thought of as a prognostic tool, but should be used to optimize clinical assistance, research and health services planning in paediatric critical care [9].

Considering the lack of a paediatric-specific definition of ARDS and a paucity of robust clinical trials in this population, the Pediatric Acute Lung Injury Consensus Conference (PALICC), in an effort to initiate discussion regarding optimization and consistency of care for paediatric ARDS (PARDS), developed paediatric-specific definitions and recommendations on treatment and research priorities [10-12]. As in the BD, the onset of PARDS must occur within 7 days of a known clinical insult, and respiratory failure must not be fully explained by cardiac failure or fluid overload. To grade disease severity, the PALICC used the oxygenation index (OI) but if patients are under non-invasive support and arterial blood gas was not available, the oxygen saturation index (OSI) rather than the $\mathrm{PaO}_{2} / \mathrm{FiO}_{2}$ ratio was used. The introduction of OSI allows the application of a standardized definition to children without an arterial line [13]. According to a recent study, applying the PALICC definition more paediatric patients with ARDS may be identified and the mortality rate may be lowered except for the more severe group [14]. Epidemiological data and animal studies suggest there are age-dependent differences in distribution, causes and peculiarity of ARDS, whereas the pathophysiology of ARDS does not change. It is important to understand the differences to identify new therapeutic interventions to prevent/modulate lung injury and improve repair [15].

\section{Incidence of ARDS}

The lack of an accepted validated definition for ARDS and the dearth of prospective studies mean that a wide range in the incidence is quoted in the literature. Before the availability of current definitions, the estimated incidence in the USA ranged from 50,000 to 190,000 - nearly a fourfold difference [16]. In 2005 Rubenfled et al. [17], in a prospective cohort study to address some of these limitations, concluded that the incidence of ALI/ARDS in the USA was substantially higher (2.5-5 times for ALI and 2-40 times for ARDS) than previously considered. They estimated that in the USA there are 190,600 cases of ALI annually associated with a staggering 3.6 million hospital days.

While we know that ALI/ARDS occurs less often in children and infants, large numbers are nevertheless affected-in the USA an estimated 2,500-9,000 children have ARDS, contributing to 500-2,000 deaths each year [18]. If compared to adults ARDS in children shows a lower mortality, this is probably due to a more frequent infectious trigger. A prospective multicentre study in Australia and New Zealand using American-European Consensus Conference guidelines showed a population incidence of 2.95/100,000 in children under 16 years of age. While ALI accounted for just $2.2 \%$ of admissions to paediatric intensive care, mortality was high (35\%) [19]. Similarly, a retrospective observational study in The Netherlands in children aged 0-16 years reported an incidence of 2.2 per 100,000 per year and a mortality rate of $20.4 \%$ [20]. The reported incidence of paediatric ARDS is lower compared to that in adults but data are underestimated because the AECC definition is used. ARDS is still an underdiagnosed and undertreated condition with high mortality and major social and economic costs. There is clearly a significant need for an improved therapeutic strategy for the management of paediatric patients with ARDS.

\section{Mechanism of Surfactant Deficiency in ARDS}

Natural pulmonary surfactant plays an essential role in lung physiology; it is responsible for lowering surface tension within the alveoli and maintaining the functional integrity of the distal airways. It is a phospholipoprotein formed and stored by type II alveolar cells. The main lipid component of surfactant, DPPC, reduces surface tension by covering the air-water interface of alveoli due to its hydrophilic head groups that stay in the water and its hydrophobic tails, which face towards the air. Lack of surfactant results in respiratory failure, secondary to atelectasis, alveolar flooding and severe hypoxaemia. Since the advent of exogenous surfactant replacement therapy, mortality from respiratory distress syndrome in neonates has been reduced by $>50 \%$ [21]. Surfactant deficiency in hyaline membrane disease is well described, and it has also been recently suggested that other mechanisms promote the quantitative dysfunction of surfactant in the lungs of neonates causing an ARDS-like appearance. It is known that in the paediatric age group ARDS is due to a severe lung inflammation and to qualitative and quantitative surfactant deficiencies $[22,23]$. Even though surfactant abnormalities in ARDS are not the primary pathogenic factors, surfactant deficiency, either in the presence or absence of type II 
pneumocyte alterations, may result from primary or secondary inhibition/inactivation of pulmonary surfactant in the alveolar space $[16,24,25]$. Type II secretory phospholipases A2 (sPLA2) is an enzyme that plays a key role in this cascade, correlating with the clinical severity of patients [26]. An increased activity of sPLA2 has been detected in adult patients and in children affected by ARDS, confirming that its pathophysiology is the same across a range of ages. sPLA2 promotes inflammation and directly catabolizes surfactant phospholipids through the hydrolysis of dipalmitoil-phosphatydil-cholina (DDPC) [26-28]. Moreover, this enzyme causes the inactivation of exogenous surfactant [29].

Surfactant deficiency and inactivation will further induce alveolar collapse and pulmonary oedema, leading to the characteristic pathophysiology of ARDS. ARDS is associated with direct and indirect (systemic) pulmonary causes-for the former clinical trial evidence suggests that exogenous surfactant therapy shows greater efficacy while in the latter multi-organ pathology significantly affects long-term outcomes, reducing the effectiveness of pulmonary-based therapies such as exogenous surfactant. Surfactant dysfunction in ARDS is most prominent in the acute exudative phase of disease, and it is here where surfactant therapy has the greatest theoretical benefits [30].

\section{Surfactant: The Solution to This Now Well- Defined Problem?}

Despite the fact that surfactant deficiencies occur in patients with ARDS, trials of exogenous surfactant therapy in adults have had variable success in improving long-term outcomes. Only three specific interventions-the use of low tidal volumes, prone positioning and neuromuscular blockade early in the course of severe ARDS-have been shown to decrease mortality in adult patients with ARDS [25, 30, 31]. However, exogenous surfactant may improve outcomes in infants and children (Table 1) [32-48]. For almost a quarter of a century there have been reports of the benefits of exogenous surfactant in infants and children with acute respiratory failure or ARDS. One of the early studies by Auten et al. [39], in full-term neonates with respiratory failure associated with pneumonia and meconium aspiration syndrome, showed that intratracheal calf lung surfactant significantly improved oxygenation.

Table 1 Overview of case histories and clinical trials demonstrating the benefits of exogenous surfactant therapy in children/infants/babies with acute respiratory failure or acute lung injury (ALI)/acute respiratory distress syndrome (ARDS) (adapted from Raghavendran [25])

\begin{tabular}{|c|c|c|c|c|}
\hline Study & Patients $(N)$ & Disease or syndrome & Surfactant & Outcomes \\
\hline $\begin{array}{l}\text { Fettah et al. } \\
\text { [48] }\end{array}$ & Baby (1) & $\begin{array}{l}\text { ARDS secondary to near } \\
\text { drowning }\end{array}$ & Curosurf $^{\circledR}$ & $\begin{array}{l}\text { Rapid and persistent improvement after } 2 \text { doses of Curosurf }{ }^{\circledR} \\
(100 \mathrm{mg} / \mathrm{kg} \text { body weight, } 1.25 \mathrm{ml} / \mathrm{kg})\end{array}$ \\
\hline $\begin{array}{l}\text { Willson et al. } \\
\text { [45] }\end{array}$ & $\begin{array}{l}\text { Children }(110 \\
\text { enrolled) }\end{array}$ & ARDS & Infasurf $\left.^{(}\right)$ & $\begin{array}{l}\text { No immediate improvement in oxygenation: study stopped at } \\
\text { sponsor's request }\end{array}$ \\
\hline $\begin{array}{l}\text { Willson et al. } \\
\text { [34] }\end{array}$ & Children (152) & $\begin{array}{l}\text { ARDS from multiple } \\
\text { causes }\end{array}$ & Infasurf $^{\circledR}$ & Improved oxygenation and ventilation \\
\hline $\begin{array}{l}\text { Moller et al } \\
{[38]}\end{array}$ & Children (35) & ARDS, multiple causes & Alveofact ${ }^{\circledR}$ & Improved oxygenation \\
\hline $\begin{array}{l}\text { Hermon et al. } \\
{[36]}\end{array}$ & Children (19) & $\begin{array}{l}\text { ARDS + post-op } \\
\text { cardiac }\end{array}$ & $\begin{array}{l}\text { Curosurf }^{\circledR} \text { or } \\
\text { Alveofact }^{\circledR}\end{array}$ & Improved oxygenation \\
\hline $\begin{array}{l}\text { Herting et al. } \\
\text { [37] }\end{array}$ & Children (8) & Pneumonia & Curosurf ${ }^{\circledR}$ & Improved oxygenation \\
\hline $\begin{array}{l}\text { Luchetti et al. } \\
{[44,46]}\end{array}$ & $\begin{array}{l}\text { Infants }(20 \\
\text { and } 40)\end{array}$ & RSV bronchiolitis & Curosurf $^{(\circledR)}$ & Improved oxygenation \\
\hline $\begin{array}{l}\text { Tibby et al. } \\
\text { [47] }\end{array}$ & Infants (19) & $\begin{array}{l}\text { Respiratory syncytial } \\
\text { virus bronchiolitis }\end{array}$ & Survanta $^{\circledR}$ & $\begin{array}{l}\text { More rapid improvement in oxygenation and ventilation indices } \\
\text { over the first } 60 \mathrm{~h} \text { of ventilation }\end{array}$ \\
\hline $\begin{array}{l}\text { Lopez-Herce } \\
\text { et al. [35] }\end{array}$ & Children (20) & $\begin{array}{l}\text { ARDS + post-op } \\
\text { cardiac }\end{array}$ & Curosurf $^{(\circledR)}$ & Improved oxygenation \\
\hline $\begin{array}{l}\text { Willson et al } \\
{[32,33]}\end{array}$ & $\begin{array}{l}\text { Children }(29 \\
\text { and } 42)\end{array}$ & $\begin{array}{l}\text { ARDS from multiple } \\
\text { causes }\end{array}$ & Infasurf $^{\circledR}$ & Improved oxygenation \\
\hline $\begin{array}{l}\text { Findlay et al. } \\
\text { [43] }\end{array}$ & Infants (40) & Meconium aspiration & Survanta ${ }^{\circledR}$ & $\begin{array}{l}\text { Improved oxygenation decreased pneumothorax and } \\
\text { mechanical ventilation }\end{array}$ \\
\hline $\begin{array}{l}\text { Lotze et al. } \\
{[40,41]}\end{array}$ & $\begin{array}{r}\text { Infants }(28 \\
\text { and } 328)\end{array}$ & $\begin{array}{l}\text { ECMO, multiple } \\
\text { indications }\end{array}$ & Survanta $^{\circledR}$ & Improved oxygenation, decreased ECMO \\
\hline $\begin{array}{l}\text { Khammash } \\
\text { et al. [42] }\end{array}$ & Infants $(20)$ & $\begin{array}{l}\text { Meconium aspiration } \\
\text { syndrome }\end{array}$ & bLES $^{\circledR}$ & Improved oxygenation in $75 \%$ of patients \\
\hline
\end{tabular}


Similarly, intratracheal surfactant moderately improved oxygenation in children with secondary pulmonary pathology or systemic disease [35]. Following the positive results of a pilot trial, Willson et al. [32] conducted a prospective, randomized, controlled trial in 42 children (aged 1 day to 18 years) with hypoxaemic respiratory failure. Results showed intratracheal administration of calfactant was well tolerated and associated with a rapid improvement in oxygenation, earlier extubation and decreased requirement for intensive care [33]. The same group conducted a similar multicentre, randomized, placebo-controlled trial using a larger cohort (152) of patients with ARDS [34]. Endotracheal surfactant improved oxygenation and significantly decreased mortality (27/75 vs. $15 / 77$ in the placebo and treated groups, respectively). There were no differences in long-term complications. In contrast with the previous trial, the duration of respiratory failure was not improved with calfactant with a mean duration of ventilation and length of hospital stay being similar in the two groups. The authors suggest this may be due to the disproportionate survival of marginal surfactanttreated patients and, paradoxically, increased survival may increase the need for prolonged supportive care. Post-hoc analysis demonstrated that improvements with surfactant occurred only in those patients with direct lung injury (pneumonia, aspiration or near drowning), and so it was decided to focus on a more homogeneous population of children with direct injury. 110 paediatric patients (aged from 37 weeks post-conception to 18 years) with direct ARDS were randomized to receive either surfactant or placebo (air) within $48 \mathrm{~h}$ of intubation and initiation of mechanical ventilation [45]. Unlike previous studies there appeared to be no improvement in oxygenation with surfactant administration. This was unexpected as only patients with direct lung injury (the subgroup that appeared to benefit most in the ad hoc analysis) were enrolled. The study was stopped early at the sponsor's request. The authors proposed three possible contributory factors for the lack of response: surfactant volume used was more concentrated, it was administered without a recruitment manoeuvre and instillation was performed in two rather than four aliquots with two rather than four position changes during administration. This study had an important bias because it evaluated oxygenation only with saturation in young patients where the amount of fetal haemoglobin is unpredictable. Moreover, a mixed adult-paediatric population was enrolled before the BD and PALICC definition were published. Jat and Chawla [49] reviewed three studies with a total of 79 patients on the use of surfactant therapy in the management of bronchiolitis in critically ill infants and concluded that surfactant had positive effects on the duration of mechanical ventilation, duration of time spent in the intensive care unit, oxygenation and carbon dioxide elimination. When the results of the Luchetti 1998 study were excluded (extreme heterogeneity of the study population), the duration of mechanical ventilation was significantly shorter in the surfactant group. No adverse events and no complications were reported. The authors concluded there is a need for large trials and cost-effectiveness data before the use of surfactant can be universally recommended in infants with bronchiolitis.

In summary, clinical trials (controlled and uncontrolled) reported that exogenous surfactant therapy could be beneficial in children and infants with ARDS/ALI without significant adverse long-term effects.

\section{How to Explain this Dichotomy: What Should We be Doing in the Clinic?}

Surfactant has proven efficacy in pre-term babies so why are results inconsistent in infants and children? Marraro et al. [50] outlined possible factors that could account for the inconsistent results. One possible reason is the different origins of lung pathologies - a deficiency of surfactant in preterm babies can be resolved by the administration of exogenous surfactant, but in infants and children in addition to reduced surfactant production there may also be inhibition/inactivation of any surfactant produced. In these patients it is necessary to first remove the inhibitors (for example, inflammatory mediators) before giving surfactant. A second reason could be the type of lung damage-we have seen that in patients with direct lung injury (for example bronchiolitis, near drowning) exogenous surfactant is effective in improving gas exchange and survival while patients with indirect lung injury do not show similar outcomes [51]. A third possible reason is the mode of administration of surfactant therapy. In recent years, there have been some experiences of alternative, less invasive methods of the administration of surfactant, but evidence supporting the most appropriate method does not exist. [52] Bronchoalveolar lavage (BAL) with normal saline and surfactant has the advantage of facilitating a synergistic effect that allows removal of inhaled material, the recruitment of non-ventilating areas and the maintenance of surfactant pool size. It may be that BAL with diluted surfactant allows rapid absorption of the surfactant at the air/liquid interface, which blocks the progression of pathological lung disease and in turn disrupts the inflammatory cycle [49, 53]. Timing of surfactant therapy may also be important: if treatment is started early there could be an improved chance of success, but definite timing has not been established [48]. Finally, it is now recognized that the type of surfactant used plays an important role [51]. Considering surfactant composition and the important role of sPLA2 on pathophysiology of lung damage in ARDS, 
Table 2 Possible mechanisms and possible solutions for surfactant failure in paediatric acute respiratory distress syndrome (PARDS)

\begin{tabular}{ll}
\hline Possible mechanism & Possible solution \\
\hline sPLA2 inactivation & Use of surfactant refractory to sPLA2 inactivation \\
Failure to remove PARDS triggers & Adoption of anti-inflammatory agents, antibiotics, anti-viral therapy \\
Lack of knowledge of effective dose/lavage ratio & Modification of ratio based on BAL studies \\
Lack of knowledge of effective dose & Modification of dose \\
Lack of knowledge of effective procedure & Use of bronchoscope and bronchoalveolar lavage \\
Composition of surfactant & Use of more effective one \\
Wrong timing & Start earlier the treatment \\
Poor ventilated lung areas & Lung recruitment by ventilation, bronchial toilette, prone position \\
\hline
\end{tabular}

also due to a surfactant inactivation, some strategies might be considered. For example, animal studies suggest the lung-protective effect of surfactant refractory to sPLA2 inactivation or the positive action of surfactant in directly inhibiting sPLA2. Moreover, surfactant might spread antiinflammatory agents in an ARDS lung [54-56]. Table 2 shows the possible mechanisms for surfactant failure in PARDS.

\section{Surfactant Administration Via Bronchoalveolar Lavage: The Way Forward?}

BAL with diluted surfactant allows rapid absorption of surfactant at the air/liquid interface. Animal studies indicate that optimal results are obtained when BAL using a diluted surfactant solution was followed by a supplementation of exogenous surfactant with regular instillation [57]. This procedure allows better distribution of the exogenous surfactant in the lung, reduces the total amount of surfactant used and benefits from the detergent proprieties of surfactant as a safe and potent lavage solution. There is limited evidence from clinical trials in humans but surfactant BAL seems to act better than simple instillation as it uses a larger volume and has improved peripheral distribution especially in severely injured lungs. BAL removes inflammatory factors that inactivate surfactant and reduces the dosage of exogenous surfactant left in the lungs after lavage. There are several case reports describing BAL with diluted surfactant in ARDS children using either bronchoscope manoeuvres (older children) or direct tracheal lavages (smaller children) but no definitive data exist. Despite ARDS, the aetiologies were very different (sepsis, near drowning, trauma and aspiration syndrome), and all of them showed a rapid decrease of ventilator settings and improvement of lung mechanics after the treatment [58-60]. Unfortunately, insufficient data exist regarding many open questions on this therapeutic strategy. There is a lack of knowledge with regard to the best surfactantlavage ratio, the adequate dosage after lavage, the best timing for administration of the treatment, the way to perform the procedure and how to ventilate the patient after treatment. More data are necessary to better understand BAL composition in animal models and in vivo patients of different ages in order to attain answers to these questions. Studies on this topic are difficult of perform in Pediatric Intensive Care Units due to the small numbers and the logistical aspects (necessity for laboratories and economic support). A standardized procedure and common guidelines for this topic are necessary.

\section{Compliance with Ethical Standards}

This article was written according to acceptable ethical standards.

Funding Editorial assistance for the preparation of this manuscript was provided by EDRA, Milan, Italy. This assistance was funded by Chiesi Farmaceutici Spa.

Conflict of interest A. Amigoni, A. Pettenazzo, V.Stritoni have no conflicts to declare. M. Circelli is an employee of Chiesi Farmaceutici Spa.

Open Access This article is distributed under the terms of the Creative Commons Attribution-NonCommercial 4.0 International License (http://creativecommons.org/licenses/by-nc/4.0/), which permits any noncommercial use, distribution, and reproduction in any medium, provided you give appropriate credit to the original author(s) and the source, provide a link to the Creative Commons license, and indicate if changes were made.

\section{References}

1. Ware LB, Matthay MA. The acute respiratory syndrome. N Engl J Med. 2000;342:1334-49.

2. Ashbaugh DG, Bigelow DB, Petty TL, Levine BE. Acute respiratory distress in adults. Lancet. 1967;2:319-23.

3. Petty TL, Ashbaugh DG. The adult respiratory distress syndrome. Clinical features, factors influencing prognosis and principles of management. Chest. 1971;60:233-9.

4. Bernard GR, Artigas A, Brigham KL, Carlet J, Falke K, Hudson L, Lamy M, Legall JR, Morris A, Spragg R. The AmericanEuropean Consensus Conference on ARDS. Definitions, mechanisms, relevant outcomes, and clinical trial coordination. Am J Respir Crit Care Med. 1994;149:818-24.

5. ARDS Definition Task Force, Ranieri VM, Rubenfeld GD, Thompson BT, Ferguson ND, Caldwell E, Fan E, Camporota L, 
Slutsky AS. Acute respiratory distress syndrome: the Berlin definition. JAMA. 2012;307:2526-33.

6. Camporota L, Ranieri VM. What's new in the "Berlin" definition of acute respiratory distress syndrome? Minerva Anestesiol. 2012;78(10):1162-6.

7. Angus DC. The acute respiratory distress syndrome: what's in a name? JAMA. 2012;20(307):2542-4.

8. De Luca D, Piastra M, Chidini G, Tissieres P, Calderini E, Essouri S, Medina Villanueva A, Vivanco Allende A, PonsOdena M, Perez-Baena L, et al. The use of the Berlin definition for acute respiratory distress syndrome during infancy and early childhood: multicenter evaluation and expert consensus. Intensive Care Med. 2013;39:2083-91.

9. Barreira ER, Munoz GO, Cavalheiro PO, Suzuki AS, Degaspare NV, Shieh HH, Martines JA, Ferreira JC, Lane C, Carvalho WB, et al. Epidemiology and outcomes of acute respiratory distress syndrome in children according to the Berlin definition: a multicenter prospective study. Crit Care Med. 2015;43:947-53.

10. Thomas NJ, Jouvet P, Willson D. Acute lung injury in childrenkids really aren't just "little adults". Pediatr Crit Care Med. 2013;14:429-32.

11. The Pediatric Acute Lung Injury Consensus Conference Group. Pediatric acute respiratory distress syndrome: consensus recommendations from the pediatric acute lung injury consensus conference. Pediatr Crit Care Med. 2015;16:428-39.

12. Rotta AT, Piva JP. Pediatric acute respiratory distress syndrome: much more than little acute respiratory distress syndrome. Pediatr Crit Care Med. 2015;16(5):483.

13. Ferguson ND, Kacmarek RM, Chiche JD, Singh JM, Hallett DC, Mehta S, Stewart TE. Screening of ARDS patients using standardized ventilator settings: Influence on enrollment in a clinical trial. Intensive Care Med. 2004;30:1111-6.

14. Parvathaneni K, Belani S, Leung D, Newth CJL, Khemani RG. Evaluating the performance of the pediatric acute lung injury consensus conference definition if acute respiratory distress syndrome. Pediatr Crit Care Med. 2017;18:17-25.

15. Smith LS, Zimmerman JJ, Martin TR. Mechanisms of acute respiratory distress syndrome in children and adults: a review and suggestions for future research. Pediatr Crit Care Med. 2013;14(6):631-43.

16. Willson DF, Chess PR, Notter RH. Surfactant for pediatric acute lung injury. Pediatr Clin N Am. 2008;55(3):545-75.

17. Rubenfeld GD, Caldwell E, Peabody E, Weaver J, Martin DP, Neff M, Stern EJ, Hudson LD. Incidence and outcomes of acute lung injury. N Engl J Med. 2005;353:1685-93.

18. Randolph AG. Management of acute lung injury and acute respiratory distress syndrome in children. Crit Care Med. 2009;37(8):2448-54

19. Erickson S, Schibler A, Numa A, Nuthall G, Yung M, Pascoe E, Wilkins B, Paediatric Study Group, Australian and New Zealand Intensive Care Society. Acute lung injury in pediatric intensive care in Australia and New Zealand: a prospective, multicenter, observational study. Pediatr Crit Care Med. 2007;8:317-23.

20. Kneyber MC, Brouwers AG, Caris JA, Chedamni S, Plötz FB. Acute respiratory distress syndrome: is it underrecognized in the pediatric intensive care unit? Intensive Care Med. 2008;34:751-4.

21. Sweet DG, Carnielli V, Greisen G, Hallman M, Ozek E, Plavka R, Saugstad OD, Simeoni U, Speer CP, Vento M, Visser GH, Halliday HL. European consensus guidelines on management of respiratory distress syndrome-2016 update. Neonatology. 2017;111(2):107-25.

22. Playfor SD, Nootigattu VK. Exogenous surfactant in paediatric acute lung Injury and acute respiratory distress syndrome. Curr Drug Saf. 2006;1:159-68.
23. Baudouin SV. Exogenous surfactant replacement in ARDS-one day, someday, or never? N Engl J Med. 2004;35:853-5.

24. Dahlem P, van Aalderen WM, Bos AP. Pediatric acute lung injury. Pediatr Respir Rev. 2007;8:348-62.

25. Marraro GA, Lucchetti M, Spada C, Galassini E, Giossi M, Piero AM. Selective medicated (normal saline and exogenous surfactant) bronchoalveolar lavage in severe aspiration syndrome in children. Pediatr Crit Care Med. 2007;8:476-81.

26. De Luca D, Minucci A, Cogo P, Capoluongo ED, Conti G, Pietrini D, Carnielli VP, Piastra M. Secretory phospholipase A2 pathway during pediatric acute respiratory distress syndrome: a preliminary study. Pediatr Crit Care Med. 2011;12(8):e20-4.

27. Kim DK, Fukuda T, Thompson BT, Cockrill B, Hales C, Bonventre JV. Bronchoalveolar lavage fluid phospholipase A2 activities are increased in human adult respiratory distress syndrome. Am J Physiol. 1995;269(1 Pt 1):L109-18.

28. De Luca D, Lopez-Rodriguez E, Minucci A, Venditelli F, Gentile L, Stival E, Conti G, Piastra M, Antonelli M, Echaide M, PerezGil J, Capoluongo ED. Clinical and biological role of secretory phospholipase A2 in acute respiratory distress syndrome infants. Crit Care. 2013;17(4):R163.

29. Touqui L, Arbibe L. A role for phospholipase A2 in ARDS pathogenesis. Mol Med Today. 1999;5(6):244-9.

30. Raghavendran K, Willson D, Notter RH. Surfactant therapy for acute lung injury and acute respiratory distress syndrome. Crit Care Clin. 2011;27:525-59.

31. Tonelli AR, Zein J, Adams J, Ioannidis JPA. Effects of interventions on survival in acute respiratory distress syndrome: an umbrella review of 159 published randomized trials and 29 metaanalyses. Intensive Care Med. 2014;40:769-87.

32. Willson DF, Jiao JH, Bauman LA, Zaritsky A, Craft H, Dockery K, Conrad D, Dalton H. Calf's lung surfactant extract in acute hypoxemic respiratory failure in children. Crit Care Med. 1996;24:1316-22.

33. Willson DF, Jiao JH, Bauman LA, Zaritsky A, Craft H, Dockery $\mathrm{K}$, Conrad D, Dalton H. Instillation of calf lung surfactant extract (calfactant) is beneficial in pediatric acute hypoxemic respiratory failure. Crit Care Med. 1999;27:188-95.

34. Willson DF, Thomas NJ, Markovitz BP, Bauman LA, DiCarlo JV, Pon S, Jacobs BR, Jefferson LS, Conaway MR, Egan EA, et al. Effect of exogenous surfactant (calfactant) in pediatric acute lung injury: a randomized controlled trial. JAMA. 2005;293:470-6.

35. Lopez-Herce J, de Lucas N, Carrillo A, Bustinza A, Moral R. Surfactant treatment for acute respiratory distress syndrome. Arch Dis Child. 1999;80:248-52.

36. Hermon MM, Golej J, Burda G, Boigner H, Stoll E, Vergesslich K, Strohmaier W, Pollak A, Trittenwein G. Surfactant therapy in infants and children: three years experience in a pediatric intensive care unit. Shock. 2002;17:247-51.

37. Herting E, Moller O, Schiffman JH, Robertson B. Surfactant improves oxygenation in infants and children with pneumonia and acute respiratory distress syndrome. Acta Paediatr. 2002;91:1174-8.

38. Möller JC, Schaible T, Roll C, Schiffmann JH, Bindl L, Schrod L, Reiss I, Kohl M, Demirakca S, Hentschel R. Treatment with bovine surfactant in severe acute respiratory distress syndrome in children: a randomized multicenter study. Intensive Care Med. 2003;29:437-46.

39. Auten RL, Notter RH, Kendig JW, Davis JM, Shapiro DL. Surfactant treatment of full-term newborns with respiratory failure. Pediatrics. 1991;87:101-7.

40. Lotze A, Knight GR, Martin GR, Bulas DI, Hull WM, O’Donnell RM, Whitsett JA, Short BL. Improved pulmonary outcome after exogenous surfactant therapy for respiratory failure in term 
infants requiring extracorporeal membrane oxygenation. J Pediatr. 1993;122:261-8.

41. Lotze A, Mitchell BR, Bulas DI, Zola EM, Shalwitz RA, Gunkel JH. Multicenter study of surfactant (beractant) use in the treatment of term infants with severe respiratory failure. J Pediatr. 1998;132:40-7.

42. Khammash H, Perlman M, Wojtulewicz J, Dunn M. Surfactant therapy in full-term neonates with severe respiratory failure. Pediatrics. 1993;92:135-9.

43. Findlay RD, Taeusch HW, Walther FJ. Surfactant replacement therapy for meconium aspiration syndrome. Pediatrics. 1996;97:48-52.

44. Luchetti M, Casiraghi G, Valsecchi R, Galassini E, Marraro G. Porcine-derived surfactant treatment of severe bronchiolitis. Acta Anaesthesiol Scand. 1998;42:805-10.

45. Willson DF, Thomas NJ, Tamburro R, Truemper E, Truwit J, Conaway M, Traul C, Egan EE, Pediatric Acute Lung and Sepsis Investigators Network. Pediatric calfactant in acute respiratory distress syndrome trial. Pediatr Crit Care Med. 2013;14:657-65.

46. Luchetti M, Ferrero F, Gallini C, Natale A, Pigna A, Tortorolo L, Marraro G. Multicenter, randomized, controlled study of porcine surfactant in severe respiratory syncytial virus-induced respiratory failure. Pediatr Crit Care Med. 2002;3:261-8.

47. Tibby SM, Hatherill M, Wright SM, Wilson P, Postle AD, Murdoch IA. Exogenous surfactant supplementation in infants with respiratory syncytial virus bronchiolitis. Am J Respir Crit Care Med. 2000;162(4 Pt 1):1251-6.

48. Fettah N, Dilli D, Beken S, Zenciroglu A, Okumuş N. Surfactant for acute respiratory distress syndrome caused by near drowning in a newborn. Pediatr Emerg Care. 2014;30(3):180-1.

49. Jat KR, Chawla D. Surfactant therapy for bronchiolitis in critically ill infants. Cochrane Database Syst Rev. 2015;8:CD009194.

50. Marraro GA. Surfactant in child and adult pathology: is it time to review our acquisitions? Pediatr Crit Care Med. 2008;9(5):537-8.

51. Spragg RG, Lewis JF, Wurst W, Häfner D, Baughman RP, Wewers MD, Marsh JJ. Treatment of acute respiratory distress syndrome with recombinant surfactant protein C surfactant. Am J Respir Crit Care Med. 2003;167:1562-6.

52. Biban P, Chini L, Bonetti P, Sacco F, Zaglia F, Santuz P. Exogenous surfactant replacement: how to deliver it? Acta Biomed. 2012;83(Suppl 1):27-32.

53. Strohmaier W, Trupka A, Pfeiler C, Thurnher M, Khakpour Z, Gippner-Steppert C, Jochum M, Redl H. Bilateral lavage with diluted surfactant improves lung function after unilateral lung contusion in pigs. Crit Care Med. 2005;33:2286-93.

54. Boet A, Brat R, Aguilera SS, Tissieres P, De Luca D. Surfactant from neonatal to pediatric ICU: bench and bedside evidence. Minerva Anestesiol. 2012;80(12):1345-56.

55. Preub S, Scheiermann J, Stadelmann S, Omam FD, WinotoMorbach S, Lex D, von Bismarck P, Adam-Klages S, KnerlichLukoschus F, Wesch D, Held-Feindt J, Uhlig S, Shutze S, Krause MF. 18:1/18:1 Dioleoyl-phosphatidylglycerol prevents alveolar epithelial apoptosis and profibrotic stimulus in neonatal piglets model of acute respiratory distress syndrome. Pulm Pharmacol Ther. 2014;28(1):25-34.

56. Pilon AL. Rationale for the development of recombinant human $\mathrm{CC} 10$ as a therapeutic for inflammatory and fibrotic disease. Ann NY Acad Sci. 2000;923:280-98.

57. van der Bleek J, Plötz FB, van Overbeek FM, Heikamp A, Beekhuis H, Wildevuur RH, Okken A. surfactant in rabbits with severe respiratory failure: the effect of volume. Pedriatr Res. 1993;34:154-8.

58. Nakamura CT, Ripka JF, Mcveigh K, Kapoor N, Keens TG. Bronchoscopic instillation of surfactant in acute respiratory distress syndrome. Ped Pulmol. 2001;31:317-20.

59. Ugras M, Guraksin O, Sen TA, Narci A, Alpay F. Surfactant replacement therapy in a pediatric near-drowning case in manure. Pediatr Em Care. 2012;28:913-4.

60. Sen S, Tung K, Palmieri T, Greenhalgh DJ. Surfactant therapy for acute respiratory distress in severe pediatric burn injury: a case series. J Burn Care Res. 2012;33(2):88-91. 